REVIEW

This paper is dedicated to the $70^{\text {th }}$ anniversary of the founding of Physiologia Bohemoslovaca (currently Physiological Research)

\title{
Adrenergic Receptors Gene Polymorphisms and Autonomic Nervous Control of Heart and Vascular Tone
}

\author{
Lenka MATUŠKOVÁ ${ }^{1}$, Michal JAVORKA ${ }^{1}$ \\ ${ }^{1}$ Department of Physiology, Comenius University in Bratislava, Jessenius Faculty of Medicine in \\ Martin, Martin, Slovakia
}

Received August 31, 2021

Accepted November 23, 2021

\section{Summary}

Adrenergic receptors (ARs) are the primary targets of catecholamines released from the sympathetic nerve endings during their activation. ARs play a central role in autonomic nervous system and serve as important targets of widely used drugs. Several ARs gene polymorphisms were found to be associated with cardiovascular disease in previous clinical studies. Although more precise mechanism of the polymorphisms influence on autonomic control of cardiovascular system was studied in many previous physiological studies, their results are not unequivocal. This paper reviews the results of clinical and physiological studies focused on the impact of selected common single nucleotide polymorphisms of ARs genes involved in sympathetic control on cardiovascular system and its control. In summary, many studies assessed only a very limited range of cardiovascular control related parameters providing only very limited view on the complex cardiovascular control. The overview of partially contradicting results underlines a need to examine wider range of cardiovascular measures including their reactivity under various stress conditions requiring further study. It is expected that an effect of one given polymorphism is not very prominent, but it is suggested that even subtle differences in cardiovascular control could - on a longer time scale - lead to the development of severe pathological consequences.

\section{Key words}

Adrenergic receptors • Polymorphisms • Cardiovascular control

\section{Corresponding author}

Lenka Matuskova, Department of Physiology, Comenius University in Bratislava, Jessenius Faculty of Medicine in Martin,
Malá Hora 4C, 03601 Martin, Slovakia. E-mail: sopkova22@uniba.sk

\section{Introduction}

Adrenergic receptors (ARs) play a key role in the transmission of information within sympathetic part of autonomic nervous system (ANS). Human genome encodes 9 different types of ARs with differing pharmacological properties and localization. These receptors are located also in heart and vessels playing very important role in the cardiovascular system control and representing an important target of various medications (Ahles and Engelhardt 2014).

Cardiovascular system (CVS) disorders are among the leading cause of mortality worldwide. Genetic predisposition plays an important role in the pathogenesis of these complex diseases. Identification of the genetic factors role in the origin and development of cardiovascular disorders could bring earlier and more aimed detection of pathological processes and better prediction of future risks (Kuneš and Zicha 2009). Thanks to the progress in pharmacology, molecular biology and genetics of adrenergic signaling pathways, several gene polymorphisms associated with altered ANS function were identified during last 20 years. The gene polymorphisms in ARs genes were most often found to be associated with cardiovascular diseases, bronchial asthma, chronic obstructive pulmonary disease and obesity (Katsarou et al. 2018). These genetic variants could modify initiation and progression of CVS disorders 
but also a response to pharmacological treatment by betablockers via their influence on sympathetic control (Kenakin 2013).

ANS assessment by evaluation of various cardiovascular and hemodynamic measures provides an important information on cardiac and vascular control state. Changes in these parameters in relation to various genotypes could indicate the potentially clinically important influence of the given genotype on ANS function. A recognition of significant relations between gene polymorphism and resulting phenotype represents a progress in the better understanding of various disorders pathogenesis. In future, genotyping of individuals can contribute to the improved cardiovascular risk estimation with the perspective of earlier and more effective therapeutic intervention. It could represent an important step forward in the personalized medicine.

The major aim of this review is to summarize information from the previous studies on the influence of selected common ARs genes polymorphisms on cardiovascular control by ANS from the physiological, pathophysiological and clinical point of view.

\section{Polymorphisms of adrenergic receptors genes}

ARs belong to the large group of receptors coupled with $G$ protein ( $G$ protein coupled receptors GPCR). Their activation lead to triggering of intracellular signal pathways. Structurally, these receptors are characterized as heptahelical transmembrane receptors with extracellular amino-terminal end and intracellular carboxy-terminal end (Capote et al. 2015). GPCRs are an important part of sympathetic nervous system mediating central and peripheral effects of catecholamines - most importantly norepinephrine and epinephrine. Almost every cell has in its cytoplasmic membrane one or more subtypes of ARs. These receptors are crucial for preserving cell, organ and whole body homeostasis at rest but also under physiological or pathological stress (Brunton et al. 2008).

Human genome encodes 9 ARs grouped into 3 families: $\alpha_{1}-, \alpha_{2}$ - and $\beta$-AR. Each family is further composed of three subtypes: $\alpha_{1}\left(\alpha_{1 \mathrm{~A}}, \alpha_{1 \mathrm{~B}}, \alpha_{1 \mathrm{D}}\right), \alpha_{2}\left(\alpha_{2 \mathrm{~A}}\right.$, $\left.\alpha_{2 \mathrm{~B}}, \alpha_{2 \mathrm{C}}\right)$ and $\beta\left(\beta_{1}, \beta_{2}, \beta_{3}\right)$ ARs. Binding of ligand (agonist) on ARs trigger intracellular cell signaling pathways via their binding on heterotrimeric $G$ protein where specific type of $G$ protein depends on the receptor family. Namely, $\alpha_{1}$-ARs are coupled with $G_{\alpha q}$ protein activating phospholipase C. $\mathrm{G}_{\alpha \mathrm{i}}$ protein is coupled with
$\alpha_{2}$-AR causing an inhibition of adenylyl cyclase. $\beta$-ARs are coupled with $G_{\alpha s}$ proteins stimulating adenylyl cyclase (Ciccarelli et al. 2017) (Fig. 1).

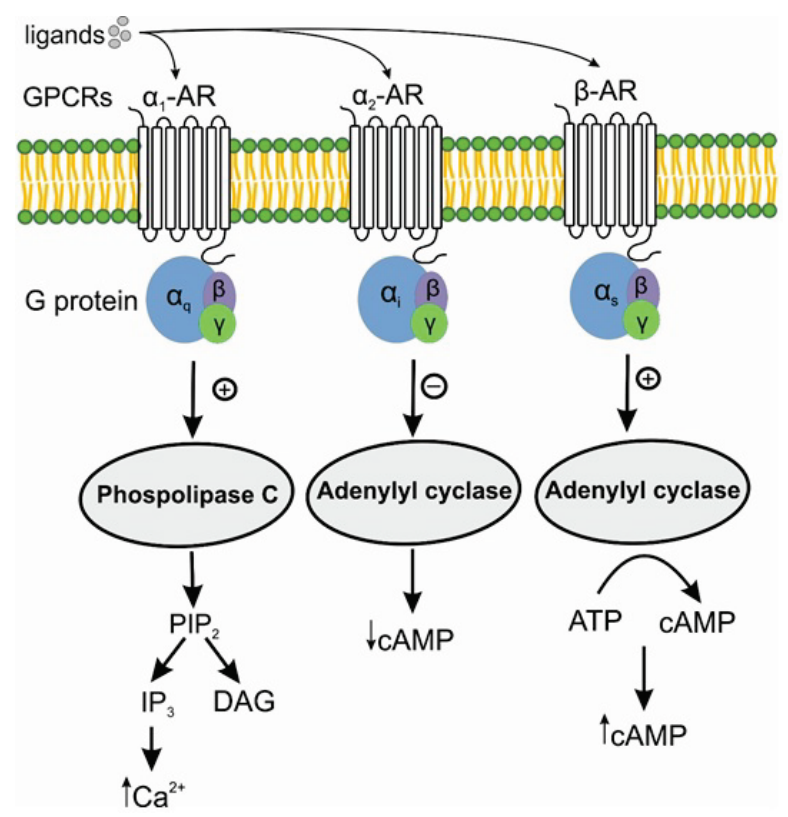

Fig. 1. Signal pathways of ARs associated with $G$ protein activation. After activation of GPCR by ligand binding on AR, inactive heterotrimeric $G$ protein dissociates into two separate active subunits $\mathrm{Ga}$ and $\mathrm{G} \beta Y$. Various types of $\mathrm{G}$ proteins lead to specific intracellular effects. While Gaq activates phospholipase $\mathrm{C}$ resulting in the hydrolysis of phosphatidylinositol 4,5-bisphosphate (PIP2) releasing inositol 1,4,5-triphosphate (IP3) and diacylglycerol (DAG), Gai inhibits adenylyl cyclase activity and Gas activates adenylyl cyclase activity influencing the intracellular level of cyclic adenosine monophosphate (CAMP) as an important second messenger.

In the cardiovascular system, catecholamines through ARs play a very important role in the control of heart and vessels. ARs are abundant in cardiovascular system. $\alpha_{1}$-ARs and $\alpha_{2}$-ARs are located in smooth muscle cells of vasculature and their activation leads to vasoconstriction. $\beta_{1}$-ARs are expressed in the heart and their activation results in increased heart rate (positive chronotropic effect), increased cardiac contractility (positive inotropic effect) and increased atrio-ventricular conduction velocity (positive dromotropic effect). $\beta_{2}$-ARs are expressed mostly in vascular smooth muscle, skeletal muscle and - to a lower extent - also in cardiomyocytes. Their activation leads to vasodilation and as a consequence to an increased perfusion of target organs (Lymperopoulos et al. 2021). Taken together, ARs play role in a wide spectrum of cardiovascular control mechanisms and also represent an important binding place of many currently used medicaments (Flordellis et al. 2004). 


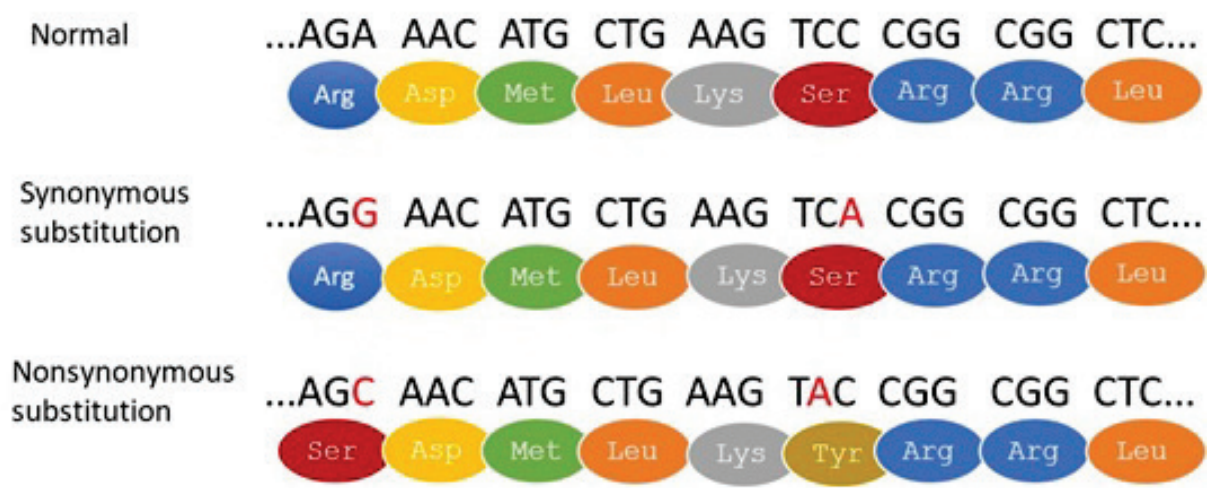

Fig. 2. Synonymous and nonsynonymous substitutions. Synonymous substitution leads to nucleotide change, but amino acid stays unchanged. Nonsynonymous substitution leads to amino acid change.

There are many genetic variations in the human genome characterized by the variability in DNA sequence among individuals. These variations are mostly in a form of single nucleotide substitution - single nucleotide polymorphisms (SNP). On average, they occur in almost every $100-300$ base pairs in human genome (Hanchard 2005). SNPs can represent synonymous or nonsynonymous substitution (Fig. 2). Synonymous substitution does not lead to any change in amino acids sequence in the encoded protein (because of the degeneracy of the genetic code), they are functionally silent and evolutionarily neutral. In contrast, nonsynonymous substitution changes the corresponding amino acid in the protein potentially influencing protein function although most of them have only very small or no effect on the resulting phenotype. Polymorphisms commonly occur in different populations, with the allelic frequency corresponding to individual SNPs varying among them (Ohta 2001).

Haplotype is a combination of alleles related to various genes along the same chromosome inherited as one unit. Various combinations of alleles related to several polymorphisms - haplotypes - may occur in a certain population more frequently. Polymorphisms in coding and regulatory regions can influence protein function or expression, potentially leading to a development of various disorders or an altered drug response (Crawford and Nickerson 2005, Hanchard 2005). Therefore, SNPs are used as molecular markers in many genetic and pharmacogenomic studies focused on various diseases. In such studies, the aim is to identify SNPs that cause changes in cellular biological processes involved in the pathogenesis of various pathological conditions. Genome-wide association studies are a typical approach to identification of increased risk related alleles involving extensive genotyping of polymorphisms in a group of patients and in a healthy control population to compare differences in genotypes for all phenotypic characteristics studied. In pharmacogenetic studies, the aim is to elucidate the effects of genetic polymorphisms on drug response. The genotyping methods usually involves the production of allele-specific products for selected polymorphisms, requiring an amplification step by polymerase chain reaction (PCR), followed by their detection (Kim and Misra 2007).

Genetic factors may represent one of the causes of a large interindividual variability in ANS activity. Polymorphisms in genes for proteins involved in ANS control may alter its function, resulting in subsequently altered autonomic control of various organ systems, including cardiovascular system. Subsequent autonomic dysregulation may be associated not only with the pathogenesis of various cardiovascular diseases (hypertension, ischemic heart disease, various cardiomyopathies), but also with the development of other diseases (e.g. obesity) (Ahles and Engelhardt 2014, Kuneš and Zicha 2009).

Except for $\alpha_{1 \mathrm{D}}$, all subtypes of $\mathrm{AR}$ are polymorphic, with genetic variations in both coding and noncoding regions of the gene (Flordellis et al. 2004). Many polymorphisms occur in AR genes, but only some of them demonstrate also functional effect. Based on the previously published literature, we selected a set of gene polymorphisms with demonstrated significant effects on the cardiovascular autonomic control assessed through various output parameters and characteristics (Table 1).

Polymorphisms of $\alpha_{I A}$-AR genes

ADRA1A gene encodes $\alpha_{1 \mathrm{~A}}$-AR localized dominantly in vascular smooth muscles but they are also present in the heart and urogenital system, gastrointestinal system and liver. $\alpha_{1 \mathrm{~A}}-\mathrm{AR}$ participates in 
Table 1. Focus of previous studies assessing effects of adrenergic receptors polymorphisms

\begin{tabular}{|c|c|c|c|}
\hline Receptor & Polymorphism & Association & References \\
\hline \multirow[t]{7}{*}{$\alpha_{1 \mathrm{~A}}-\mathrm{AR}$} & rs 1048101 & HR & Iacoviello et al. 2006, Kelsey et al. 2012 \\
\hline & & HR variability & Matsunaga et al. 2007a, Iacoviello et al. 2006 \\
\hline & & PVR & Kelsey et al. 2012 \\
\hline & & $\mathrm{BP}$ & Freitas et al. 2008, Nunes et al. 2014 \\
\hline & & hypertension & Freitas et al. 2008, Gu et al. 2006 \\
\hline & & antihypertensive treatment & Jiang et al. 2005, Zhang et al. 2009 \\
\hline & & vasovagal syncope & Hernández-Pacheco et al. 2014 \\
\hline \multirow[t]{5}{*}{$\alpha_{2 \mathrm{~A}}-\mathbf{A R}$} & rs1800544 & PVR & Kelsey et al. 2012 \\
\hline & & $\mathrm{BP}$ & $\begin{array}{l}\text { Kelsey et al. 2012, McCaffery et al. 2002, Rana et al. } \\
\text { 2007, Rosmond et al. } 2002\end{array}$ \\
\hline & & antihypertensive treatment & Kurnik et al. 2011, Yağar et al. 2011 \\
\hline & & ADHD & Schmitz et al. 2006, Polanczyk et al. 2009 \\
\hline & & metabolic disorders & Grudell et al. 2008, Lima et al. 2007 \\
\hline \multirow[t]{8}{*}{$\boldsymbol{\beta}_{1}$-AR } & rs 1801252 & HR & $\begin{array}{l}\text { Wilk et al. 2006, Kelley et al. 2018, Mahesh Kumar et } \\
\text { al. 2008, Ranade et al. } 2002\end{array}$ \\
\hline & & stroke index & Wittwer et al. 2011 \\
\hline & rs1801253 & HR & Kindermann et al. 2011 \\
\hline & & PVR & Kindermann et al. 2011 \\
\hline & & inotropy & $\begin{array}{l}\text { Bruck et al. 2005, Huntgeburth et al. 2011, Kindermann } \\
\text { et al. 2011, La Rosée et al. } 2004\end{array}$ \\
\hline & & $\mathrm{BP}$ & Tikhonoff et al. 2008 \\
\hline & & hypertension & $\begin{array}{l}\text { Gjesing et al. 2007, Johnson et al. 2011, Tikhonoff et } \\
\text { al. } 2008\end{array}$ \\
\hline & & antihypertensive treatment & $\begin{array}{l}\text { Shahin et al. 2019, Si et al. 2014, Wu et al. 2015, Chen } \\
\text { et al. 2018, Lee et al. } 2016\end{array}$ \\
\hline \multirow[t]{10}{*}{$\boldsymbol{\beta}_{2}-\mathbf{A R}$} & rs1042713 & HR & $\begin{array}{l}\text { Snyder et al. 2006, Wittwer et al. 2011, Atala et al. } \\
\text { 2015, Eisenach } \text { et al. } 2012\end{array}$ \\
\hline & & HR variability & Yang et al. 2011, Atala et al. 2015 \\
\hline & & cardiac output, stroke volume & $\begin{array}{l}\text { Rokamp et al. 2013, Snyder et al. 2006, Wittwer et al. } \\
2011\end{array}$ \\
\hline & & blood pressure & $\begin{array}{l}\text { Masuo et al. 2005a, Snieder et al. 2002, Snyder et al. } \\
2006\end{array}$ \\
\hline & rs1042714 & HR & Wittwer et al. 2011 \\
\hline & & HR variability & Atala et al. 2015, Matsunaga et al. 2007b \\
\hline & & blood pressure & $\begin{array}{l}\text { Masuo et al. 2005b, Snieder et al. 2002, Komara et al. } \\
2014\end{array}$ \\
\hline & & coronary artery disease & Li et al. 2019 \\
\hline & & overweight, obesity & Aradillas-García et al. 2017, Daghestani et al. 2012 \\
\hline & & insulin resistance & Mitra et al. 2019 \\
\hline \multirow[t]{4}{*}{$\boldsymbol{\beta}_{3}$-AR } & rs4994 & coronary artery disease & Kumar et al. 2014 \\
\hline & & hypertension & Li et al. 2018, Yang et al. 2017 \\
\hline & & overweight, obesity & Mirrakhimov et al. 2011, Xie et al. 2020 \\
\hline & & diabetes mellitus type 2 & Ryuk et al. 2017 \\
\hline
\end{tabular}

$A R$, adrenergic receptor; HR, heart rate; PVR, peripheral vascular reactivity; $B P$, blood pressure; ADHD, Attention Deficit Hyperactive Disorder 
the blood pressure control by sympathetic nerves via their vasocontriction effects on blood vessels. $\alpha_{1 \mathrm{~A}}$-AR agonists as vasoconstrictors can be used to treat hypotension, while $\alpha_{1 \mathrm{~A}}$-AR antagonists can decrease blood pressure in arterial hypertension. Activation of $\alpha_{1 \mathrm{~A}}-\mathrm{AR}$ in the heart mediates increased inotropy, cardiomyocytes hypertrophy and ischemic preconditioning of the heart (Brunton et al. 2008, Docherty 2019).

Common polymorphism of ADRA1A gene rs1048101 (Arg347Cys) localized on 8th chromosome result in nonsynonymous mutation. Substitution of adenine for guanine $(A>G)$ causes substitution of amino acid arginine (Arg) for cysteine (Cys) in amino acid position 347 - it represents a change in the translated protein potentially influencing its function. Global minor allele A frequency is $35 \%$, in Europe up to $57 \%$.

Although in vitro studies did not demonstrate any effect of polymorphic variants on receptor function (Lei et al. 2005, Shibata et al. 1996), clinical and physiological studies revealed associations between polymorphisms and several cardiovascular measures pointing towards their potential clinical significance.

Activation of vascular $\alpha_{1 \mathrm{~A}}$-ARs represents major mechanism of constriction of smooth muscle cells in vasculature. However, assessment of ADRA1A gene polymorphisms effects on phenylephrine (agonist of $\alpha_{1 \mathrm{~A}}$-ARs) mediated venoconstriction showed that genetic component explains only a small part of interindividual variability of the response. From 32 assessed ADRA1A gene polymorphisms (including common rs1048101 polymorphism), there was found association of altered response to phenylephrine mediated venoconstriction with only two SNPs (rs574647 and rs1079078). Therefore, an association between rs1048101 and venoconstriction mediated by agonist observed in previous studies was not confirmed on larger study (Adefurin et al. 2015, Sofowora et al. 2004).

On the other hand, during application of various stressors (cold stress test, mental arithmetics) rs1048101 polymorphism was associated with peripheral vascular resistance (PVR) reactivity indicating altered vasomotor control. The observed association was influenced by sex - Arg allele presence leads to lower increase of PVR in males while opposite effect (higher reactivity of PVR) was observed during cold stress test in females (Kelsey et al. 2012). In another study, rs 1048101 polymorphism was related to the occurence of vasovagal syncope (Arg allele) - potentially indicating altered vasomotor control in accordance with previous study (Hernández-
Pacheco et al. 2014). Similarly, authors observed a significant sex-dependent association of this polymorphism with heart rate reactivity on cold stress test: females with Arg allele had more prominent heart rate increase during test, while opposite was observed in males (Kelsey et al. 2012). Resting heart rate was increased in allele Cys carriers and decreased in allele Arg carriers (Iacoviello et al. 2006). Analysis of heart rate variability showed decreased values of low frequenc $\mathrm{y}$ power expressed as a percentage of total power $(\mathrm{LF}(\%))$, decreased $\mathrm{LF} / \mathrm{HF}$ ratio and increased high frequency power $(\mathrm{HF}(\%))$. Although these indices were challenged, these results potentially point towards a shift in sympatho-vagal balance towards parasympathetic dominance in allele Cys presence (Matsunaga et al. 2007a). These findings were confirmed by decreased overall and beat to beat variability (SDNN and rMSSD measures, respectively) (Iacoviello et al. 2006). However, genome wide association study of heart rate variability identified several polymorphisms in ADRAlA gene associated with heart rate variability alterations but no effect of rs1048101 polymorphism on assessed measures was found (Newton-Cheh et al. 2007). In a small stu dy (16 subjects), an association between Cys allele and lower dromotropic response before and during epinephrine infusion was found (Snapir et al. 2003). The results indicate that $\alpha_{1 \mathrm{~A}}$-ARs could play an important role not only in vessels but also in human heart.

Considering the important role of $\alpha_{1 \mathrm{~A}}$-ARs in the vascular resistance control, several studies evaluated potential influence of rs1048101 polymorphism with blood pressure values in healthy population and on arterial hypertension. Allele Cys was associated with an increased blood pressure in healthy Brazilian population (Freitas et al. 2008, Nunes et al. 2014) as well as with the hypertension (Freitas et al. 2008). In contrast, Chinese clinical study revealed association between arterial hypertension and presence of allele Arg (Gu et al. 2006). In another studies, association of this polymorphism with hypertension was not demonstrated (Iacoviello et al. 2006, Xie et al. 1999).

Pharmacogenomic studies observed interindividual variability in therapeutic response to antihypertensives. Irbesartan (angiotensin II antagonist) decreased blood pressure to a lower extent in allele Cys carriers indicating its lower effectiveness (Jiang et al. 2005). On the other hand, calcium channel blocker nifedipine decreased blood pressure in Cys allele carriers more prominently (Zhang et al. 2009). 
In conclusion, despite the dominant role of $\alpha_{1 \mathrm{~A}}$-ARs in vasomotor control, the results of previous studies did not provide clear conclusion about the effect of rs1048101 polymorphism on vascular control. Assessment of PVR is relatively cumbersome resulting in only limited information on the effects of rs1048101 polymorphism on vascular control. Indirect measures like blood pressure values are influenced by many other factors potentially obscuring subtle effects. Despite these facts, the results indicate that rs1048101 polymorphism can be related to blood pressure and its control. To further elucidate this relation, more complex studies focused on vascular control and its changes during various states are needed.

\section{Polymorphisms of $\alpha 2 A-A R$ genes}

$\alpha_{2 \mathrm{~A}}$-ARs are mostly involved in the central nervous system and cardiovascular control. ADRA2A gene encodes $\alpha_{2 \mathrm{~A}}$-ARs localized in cerebral neurons, in vascular and visceral smooth muscle cells (mediating contraction) (Skinner et al. 2018). Most importantly, $\alpha_{2 \mathrm{~A}}$-ARs are located in presynaptic endings on central and peripheral sympathetic nerves contributing to presynaptic inhibition of the norepinephrine release. Inhibition of sympathetic effects by presynaptic $\alpha_{2 \mathrm{~A}}$-ARs results in decreased peripheral vasoconstriction followed by blood pressure decrease. On the other hand, vascular $\alpha_{2 \mathrm{~A}}$-AR mediate - to a much lower extent compared to $\alpha_{1 \mathrm{~A}}$-ARs peripheral vasoconstricion (Flordellis et al. 2004).

Gene encoding $\alpha_{2 \mathrm{~A}}$-ARs is polymorphic and the most commonly studied polymorphism rs1800544 (C1291G) characterized by substitution $\mathrm{C}>\mathrm{G}$ is localized in the noncoding region of the $A D R A 2 A$ gene. Minor allele occurs in $46 \%$ of worldwide population, in Europe its frequency reaches $74 \%$.

Polymorphism rs1800544 was not analyzed in vitro - the impact of polymorphic variants on the receptor function is unclear. However, several studies revealed impact of this polymorphism on cardiovacular control indicating its effect in vivo.

Studies focused on vascular reactivity to stress demonstrated association of rs1800544 polymorphism with vascular resistance - a magnitude of PVR increase was linearly related to the number of allele $G$ copies. Similar, but less prominent, association was observed for diastolic blood pressure. Authors suggest that increased peripheral vasoconstriction results from the decreased presynaptic function of allele $G$ associated $\alpha_{2 \mathrm{~A}}$-ARs leading to a decreased inhibition of norepinephrine release (Kelsey et al. 2012). In contradiction, several studies focused on resting blood pressure values observed an increase in allele C carriers (Kelsey et al. 2012, McCaffery et al. 2002, Rana et al. 2007, Rosmond et al. 2002). Pharmacogenomic studies observed altered response to dexmedetomidine (agonist of $\alpha_{2 \mathrm{~A}}-\mathrm{AR}$ ) in relation to genotype - allele $\mathrm{C}$ carriers had a decreased hypotensive response (Kurnik et al. 2011) while allele G was associated with a prolonged effect duration (Yağar et al. 2011) potentially indicating hypofunction effect of allele $\mathrm{C}$ on the receptor. In addition, association of this polymorphism with attention deficit hyperactivity disorder (ADHD) occurence and its therapy (Schmitz et al. 2006, Polanczyk et al. 2007), as well as with obesity and metabolic disorders was found (Grudell et al. 2008, Lima et al. 2007).

In conclusion, previous studies indicate potential effect of rs 1800544 on vascular control but the results are equivocal requiring further studies.

\section{Polymorphisms of $\beta_{1^{-}}$and $\beta_{2}$-ARs genes}

$\beta$-adrenergic receptors play an important role in cellular signalling related mostly to cardiac sympathetic control. In human heart, the dominance of $\beta_{1}$-ARs over $\beta_{2}$-AR was found: ratio of $\beta_{1}$-ARs : $\beta_{2}$-AR number is $70-$ $80 \%: 30-20 \%$ in ventricles and $60-70 \%: 40-30 \%$ in atria. Thus, both ARs subtypes are involved in the positive intropic and chronotropic effects of catecholamines on the heart (Leineweber et al. 2004, Svoboda et al. 2004). Many nonsynonymous polymorphisms in $\beta$-AR genes were detected with the influence on receptor function potentially affecting cardiovascular control and involved in cardiovascular disease pathogenesis (Ahles and Engelhardt 2014).

In $A D R B 1$ gene for $\beta_{1}$-AR two common polymorphisms (rs1801252, Ser49Gly), (rs1801253, Arg389Gly) and in ADRB2 gene for $\beta_{2}$-AR another two common polymorphisms (rs1042713, Arg16Gly), (rs1042714, Gln27Glu) were found. These nonsynonymous substitutions with potential effects on receptor function were most frequently studied both in vitro and in vivo (Leineweber and Brodde 2004; Ahles and Engelhardt 2014).

In vitro studies focused on effect of polymorphic variants on $\beta_{1}$-ARs function observed in rs1801252 polymorphism altered function of receptor in the presence of allele Gly (alterations in binding affinity of agonists and antagonists, in adenylyl cyclase activity, receptor downregulation) (Levin et al. 2002, Rathz et al. 2002). 
However, another study did not confirm this polymorphism related alterations in receptor characteristics (Baker et al. 2013). Concerning rs 1801253 polymorphism, several studies agree on its hyperfunction associated with Arg allele (Joseph et al. 2004, Mason et al. 1999, Warne et al. 2012), but - similarly - another in vitro studies did not find any difference in receptor function between genotypes (Baker et al. 2013, Rochais et al. 2007). Altered receptors characteristics are connected also with both $\beta_{2}$-AR polymorphisms (rs1042713, rs 1042714) (Green et al. 1995, 1994).

In vivo studies observed association of Ser49Gly (ADRB1) polymorphism with chronotropic cardiac control - a presence of Gly allele was associated with increased resting heart rate (Wilk et al. 2006) and heart rate during exercise (Kelley et al. 2018, Mahesh Kumar et al. 2008). Paradoxically, in one study this allele was related with a decrease in heart rate (Ranade et al. 2002). Evaluating cardiovascular system reactivity to orthostasis, authors observed less expressed stroke index (stroke volume standardized to body surface area) decrease in allele Gly carriers (Wittwer et al. 2011). Other hemodynamic measures (blood pressure, cardiac output, stroke volume, PVR) and heart rate variability indices were not found to be associated with this polymorphism at rest (Iacoviello et al. 2006, Kindermann et al. 2011, Sandilands et al. 2019), or during orthostasis (Matsunaga et al. 2007b).

Arg389Gly (ADRB1) polymorphism is most often associated with inotropic heart rate control changes. Several studies evaluated cardiac inotropy by dobutamine stress echocardiography. These studies agree in an increased cardiac contractility associated with allele Arg (Bruck et al. 2005, Huntgeburth et al. 2011, Kindermann et al. 2011, La Rosée et al. 2004) in accordance with hyperfunction effect of allele Arg in vitro (Joseph et al. 2004, Warne et al. 2012). In contrast, analysis of an increase in cardiac contractility evoked by dynamic exercise did not demonstrate significant effects of Arg389Gly polymorphism on cardiac inotropy (Büscher et al. 2001, Leineweber et al. 2006, Rokamp et al. 2013, Snyder et al. 2006). After application of $\alpha_{1^{-}}, \beta_{1^{-}}$, and $\beta_{2}$-AR agonist dobutamine allele Arg was also associated with higher increase of heart rate and higher PVR underlining the suggested hyperfunction of Arg allele (Kindermann et al. 2011). This allele was further associated with an increase of diastolic blood pressure in healthy population (Tikhonoff et al. 2008), and with an increased prevalence of hypertension (Gjesing et al.
2007, Johnson et al. 2011, Tikhonoff et al. 2008). Studies focused on antihypertensive pharmacotherapy demonstrated an association of Arg allele with more pronounced effect of beta blockers on blood pressure compared to Gly alele (Shahin et al. 2019, Si et al. 2014, $\mathrm{Wu}$ et al. 2015) - it confirms indirectly Arg allele hyperfunction. On the other hand, several other studies presented better response (more prominent blood pressure decrease) as a response to beta-blockers in patients with allele Gly (Chen et al. 2018, Lee et al. 2016), or no difference in therapeutic response (Baker et al. 2013).

Many of the polymorphisms of $A D R B 1$ gene are in strong disequilibrium and some allele pairs are often inherited together in the form of haplotypes (Crawford and Nickerson 2005). In theory, separate assessment of individual polymorphisms effects could not lead to the detection of an influence of genotype on analyzed cardiovascular measures. Therefore, several studies evaluated the effects of various haplotypes - they found several significant associations or particular haplotype with alteration in blood pressure level (Mahesh Kumar et al. 2008) or in a response to pharmacotherapy of hypertension by beta-blockers (Johnson et al. 2003, Si et al. 2014).

Concluding the studies focused on two common $A D R B 1$ gene polymorphisms, Ser49Gly polymorphism has lower influence on cardiovascular system compared to Arg389Gly polymorphism where Arg allele seems to be hyperfunctional with an increased chronotropic and inotropic cardiac control effects confirming in vitro studies.

Polymorphism Gly16Arg (ADRB2) was found to be associated with heart rate - however results of studies were not consistent. Significant associations with heart rate variability were also found - lower LF and higher HF components were found (Yang et al. 2011) in accordance with increased time domain indices (SDNN, PNN50, rMSSD) in allele Arg carriers (Atala et al. 2015). In contrast, no significant associations with heart rate variability measures were found in Matsunaga et al. (2007).

Several studies observed association of this polymorphism with basic hemodynamic measures cardiac output and stroke volume - where Arg allele carriers had decreased values of these measures at rest (Eisenach et al. 2014), during exercise (Rokamp et al. 2013, Snyder et al. 2006). Accordingly, more prominent decrease in these measures was observed during orthostasis in Arg allele carriers (Wittwer et al. 2011). 
These observations indicate potential hypofunctional effect of Arg allele resulting in lower strength of cardiac contraction and subsequently in a decreased cardiac output and stroke volume. In accordance with this concept, several studies observed decreased blood pressure in Arg allele carriers (Masuo et al. 2005a, Snieder et al. 2002, Snyder et al. 2006).

Inconsistent effects on heart rate could reflect only small influence of sympathetic activity on chronotropic cardiac control at rest. Increased heart rate in Arg carriers was observed at rest (Snyder et al. 2006, Wittwer et al. 2011), but decresed heart rate values were also found at rest (Atala et al. 2015), and during handgrip test (Eisenach et al. 2012). Arg allele was associated with a more prominent increase in heart rate during orthostasis (Wittwer et al., 2011). We assume that this effect was a consequence of a compenstation of insufficient increase in cardiac contractility resulting in less prominent increase in blood pressure during orthostasis. Increased heart rate response to blood pressure change is also reflected in observed increased sensitivity of cardiac chronotropic baroreflex response (Atala et al. 2015) and following increased heart rate. These mechanisms should be confirmed by more complex study with an inclusion of a large set of hemodynamic parameters and their response to orthostatic stress.

Results of the second polymorphism Gln27Glu (ADRB2) effects analysis were less consistent. In haplotype combined with previous polymorphism Arg16Arg/Gln27Gln - a significant association with a decreased cardiac output was found (Eisenach et al. 2014), but polymorphism Gln27Glu itself analyzed separately did not demonstrate significant association indicating weaker effect of this polymorphism (Wittwer et al. 2011). Several authors assessed heart rate during various states (Atala et al. 2015, Eisenach et al. 2012) but only one study demonstrated decreased heart rate values in Glu allele carriers (Wittwer et al. 2011). This allele was related to the increased LF component of heart rate variability (Atala et al. 2015, Matsunaga et al. $2007 b$ ), but this association was not confirmed by another study (Yang et al. 2011). Furthermore, this allele was associated with increased blood pressure values in healthy probands (Masuo et al. 2005b, Snieder et al. 2002) and in hypertensive patients (Komara et al. 2014).

In recent clinical study, increased risk of cardiovascular events was associated with Glu allele in patients suffering from coronary artery disease (Li et al. 2019). Relations of this polymorphism with obesity
(Aradillas-García et al. 2017), overweight (Daghestani et al. 2012) and an increased risk of insulin resistance was also found (Mitra et al. 2019).

Concluding, from $A D R B 2$ gene polymorphisms, Gly16Arg polymorphism has more pronounced influence on cardiovascular system (hyperfunctional Arg allele) compared to Gln27Glu polymorphism.

\section{Polymorphisms of $\beta 3-A R$ genes}

$\beta_{3}$-ARs are localized in many human tissues including heart, vessels, brain, retina, gall bladder, kidneys and urinary tract but - most importantly - in fat tissue playing their major role in lipid metabolism (lipolysis). In contrast to $\beta_{1}$-ARs and $\beta_{2}$-ARs, $\beta_{3}$-ARs are expressed in myocardial tissue only in low concentrations creating only $3 \%$ from overall number of $\beta$-ARs. $\beta_{3}$-ARs play a role in control of cardiac ventricle function via their influence on endothelial nitric oxide synthase (eNOS), resulting in negative inotropic effect on the heart (Michel et al. 2020, Tavernier et al. 2003).

Single nucleotide polymorphism rs4994 (Trp64Arg) with a nucleotide substitution $\mathrm{T}>\mathrm{C}$ resulting to amino acid substitution (tryptophan is replaced by arginine) in intracellular end of transmembrane domain 1 (TMD1) is the most common polymorphism on $A D R B 3$ gene. Minor allele $\mathrm{C}$ occurs in only $8 \%$ of population in Europe and in $12 \%$ worldwide. This polymorphism attracted increased attention because of its potential role in metabolic disorders including type 2 diabetes mellitus, obesity and related states (Yang and Tao 2019).

In vitro studies focused on receptor funtion demonstrated that rs4994 polymorphism influences receptor function resulting in worsening of ligand induced cAMP accummulation (Piétri-Rouxel et al. 1997).

Clinical studies demonstrated an association of rs4994 polymorphism with coronary artery disease (allele Arg) (Kumar et al. 2014) and hypertension where metaanalysis confirmed increased systolic and diastolic blood pressure values in patients with arterial hypertension carrying genotype Trp/Arg compared to Trp/Trp genotype (Li et al. 2018, Yang et al. 2017).

Since $\beta_{3}$-ARs are primarily expressed in white and brown adipose tissues mediating lipolysis and thermogenesis, many studies focused on the metabolic effects of this polymorphism. Their conclusions agree on the significant association of this polymorphism wih altered lipids concentrations, insulin and leptin levels, and blood glucose concentration (Daghestani et al. 2018, 
Jesus et al. 2018), as well as with the risk of overweight, obesity (Mirrakhimov et al. 2011, Xie et al. 2020) and type 2 diabetes mellitus (Ryuk et al. 2017).

\section{Perspectives}

Better understanding of the genetic influence on cardiovascular autonomic control could lead to the development of well-defined strategies aimed on clinical genetic testing and on genomic medicine. Early detection of high-risk genotypes could also motivate clinicians to focus on early detection of initial stages of cardiovascular disease enabling to apply early preventive interventions to slow down progression of these pathological states. Analysis of genetic polymorphisms could also help in personalized pharmacological intervention. I.e., some patients suffering from cardiovascular diseases could receive more effective treatment based on their genotype. Regarding multifactorial disorders, genetic analysis could be of a great importance for the selected group of people with increased risk of development of these pathological states (smokers, obese patients). The awareness of having potentially increased genetic risk could lead to their better motivation to positively influence lifestyle.

\section{Conclusions}

The results of studies focused on effects of ARs gene polymorphisms indicate functional differences between alleles related to physiological effects and influence on pathogenesis of cardiovascular disorders. However, these results are not consistent and the effects of SNPs of ARs are inconclusive. Although polymorphism rs1048101 in ADRA1A gene did not lead to altered receptor properties in vitro, studies performed in human demonstrated effects on cardiovascular measures. In fact, these effects were not consistent, similarly to the effects of polymophism rs1800544 in $A D R A 2 A$ gene. The studies were mostly focused on SNPs in $A D R B 1$ and $A D R B 2$ genes where in vitro studies demonstrated altered receptor properties. In accordance, in vivo studies also revealed effects on cardiovascular control related measures. Clinical studies agree on the association of rs1801253 polymorphism with hypertension and altered response to beta-blockers. Despite many studies published on these four polymorphysmis their results are also not unequivocal. Polymorphism rs4994 in ADRB3 gene was less studied with a focus mostly on its metabolic effects.

Despite relatively high number of previous studies on this topic, they suffer from many limitations, including small sample size, very limited number of assessed cardiovascular control related measures, wide age range, examination protocol including only rest phase. These limitations could potentially lead to inconsistent and unclear results and conclusions. Given the small influence of given individual SNP, it is needed to perform more complex studies assessing wide variety of cardiovascular control output parameters under various physiological states to reveal subtle effects of genetic variations of adrenergic receptors on cardiac and vascular control.

\section{Conflict of Interest}

There is no conflict of interest.

\section{Acknowledgements}

The study was supported by grants VEGA 1/0200/19, 1/0283/21 and Grant UK/134/2021.

\section{References}

ADEFURIN A, GHIMIRE L V., KOHLI U, MUSZKAT M, SOFOWORA GG, LI C, PARANJAPE SY, STEIN CM, KURNIK D: Genetic variation in the $\alpha 1 \mathrm{~A}$-adrenergic receptor and phenylephrine-mediated venoconstriction. Pharmacogenomics J 15: 310-315, 2015. https://doi.org/10.1038/tpj.2014.69

AHLES A, ENGELHARDT S: Polymorphic variants of adrenoceptors: pharmacology, physiology, and role in disease. Pharmacol Rev 66: 598-637, 2014. https://doi.org/10.1124/pr.113.008219

ARADILLAS-GARCÍA C, CRUZ M, PÉREZ-LUQUE E, GARAY-SEVILLA ME, MALACARA JM, ADUNA R, PERALTA J, BURGUETE-GARCÍA A, ALEGRÍA-TORRES JA: Obesity is associated with the Arg389Gly ADRB1 but not with the Trp64Arg ADRB3 polymorphism in children from San Luis Potosí and León, México. J Biomed Res 31: 40-46, 2017. https://doi.org/10.7555/JBR.30.20150169

ATALA MM, GOULART A, GUERRA GM, MOSTARDA C, RODRIGUES B, MELLO PR, CASARINE DE, IRIGOYEN M-C, PEREIRA AC, CONSOLIM-COLOMBO FM: Arg16Gly and Gln27Glu $\beta 2$ adrenergic polymorphisms influence cardiac autonomic modulation and baroreflex sensitivity in healthy young Brazilians. Am J Transl Res 7: 153-161, 2015. 
BAKER JG, PROUDMAN RGW, HILL SJ: Impact of polymorphic variants on the molecular pharmacology of the two-agonist conformations of the human $\beta 1$-adrenoceptor. PLoS One 8: 32-36, 2013. https://doi.org/10.1371/journal.pone.0077582

BRUCK H, LEINEWEBER K, TEMME T, WEBER M, HEUSCH G, PHILIPP T, BRODDE OE: The Arg389Gly Beta1-adrenoceptor polymorphism and catecholamine effects on plasma-renin activity. J. Am. Coll. Cardiol. 46: 2111-2115, 2005. https://doi.org/10.1016/j.jacc.2005.08.041

BRUNTON L, PARKER K, BLUMENTHAL D, BUXTON I: Goodman \& Gilman's: Manual of Pharmacology and Therapeutics. Pharmacol Ther 2008.

BÜSCHER R, BELGER H, EILMES KJ, TELLKAMP R, RADKE J, DHEIN S, HOYER PF, MICHEL MC, INSEL PA, BRODDE OE: In-vivo studies do not support a major functional role for the Gly389Arg $\beta 1$-adrenoceptor polymorphism in humans. Pharmacogenetics 11: 199-205, 2001. https://doi.org/10.1097/00008571200104000-00003

CAPOTE LA, MENDEZ PEREZ R, LYMPEROPOULOS A: GPCR signaling and cardiac function. Eur J Pharmacol 763: 143-148, 2015. https://doi.org/10.1016/j.ejphar.2015.05.019

CHEN Liping, XIAO T, CHEN Liling, XIE S, DENG M, WU D: The Association of ADRB1 and CYP2D6 polymorphisms with antihypertensive effects and analysis of their contribution to hypertension risk. Am J Med Sci 355: 235-239, 2018. https://doi.org/10.1016/j.amjms.2017.11.002

CICCARELLI M, SORRIENTO D, COSCIONI E, IACCARINO G, SANTULLI G: Chapter 11 - Adrenergic Receptors, In: Endocrinology of the Heart in Health and Disease. Academic Press, pp 285-315, 2017. https://doi.org/10.1016/B978-0-12-803111-7.00011-7

CRAWFORD DC, NICKERSON DA: Definition and clinical importance of haplotypes. Annu Rev Med 56: 303-320, 2005. https://doi.org/10.1146/annurev.med.56.082103.104540

DAGHESTANI MHMH, WARSY A, DAGHESTANI MHMH, AL-ODAIB AN, ELDALI A, AL-EISA NA, OMER SA, HASSAN ZK: Arginine 16 glycine polymorphism in $\beta 2$-adrenergic receptor gene is associated with obesity, hyperlipidemia, hyperleptinemia, and insulin resistance in saudis. Int. J. Endocrinol. 2012: 945608, 2012. https://doi.org/10.1155/2012/945608

DAGHESTANI MM, DAGHESTANI MM, DAGHISTANI M, ELDALI A, HASSAN ZK, ELAMIN MH, WARSY A: ADRB3 polymorphism rs4994 (Trp64Arg) associates significantly with bodyweight elevation and dyslipidaemias in Saudis but not rs1801253 (Arg389Gly) polymorphism in ARDB1. Lipids Health Dis 17: 58, 2018. https://doi.org/10.1186/s12944-018-0679-7

DOCHERTY JR: The pharmacology of $\alpha 1$-adrenoceptor subtypes. Eur J Pharmacol 855: 305-320, 2019. https://doi.org/10.1016/j.ejphar.2019.04.047

EISENACH JH, MCGUIRE AM, SCHWINGLER RM, TURNER ST, JOYNER MJ, EISENACH JH, MCGUIRE AM, SCHWINGLER RM, TURNER ST, JOYNER MJ, TURNER ST, JOYNER MJ, ARG T: The Arg16/ Gly $\beta 2$-adrenergic receptor polymorphism is associated with altered cardiovascular responses to isometric exercise The Arg16 / Gly $\beta 2$-adrenergic receptor polymorphism is associated with altered cardiovascular responses to isometric exercise. Physiol Genomics 16: 323-328, 2012. https://doi.org/10.1152/physiolgenomics.00152.2003

EISENACH JH, SCHROEDER DR, PAVEY ES, PENHEITER AR, KNUTSON JN, TURNER ST, JOYNER MJ: Interactions between beta-2 adrenoceptor gene variation, cardiovascular control and dietary sodium in healthy young adults. J. Physiol. 592: 5221-5233, 2014. https://doi.org/10.1113/jphysiol.2014.276469

FLORDELLIS C, PARIS H, KARABINIS A, LYMPEROPOULOS A: Pharmacogenomics of adrenoceptors. Pharmacogenomics 5: 803-817, 2004. https://doi.org/10.1517/14622416.5.7.803

FREITAS SR, PEREIRA AC, FLORIANO MS, MILL JG, KRIEGER JE: Association of alpha1a-adrenergic receptor polymorphism and blood pressure phenotypes in the Brazilian population. BMC Cardiovase Disord 8: 1-7, 2008. https://doi.org/10.1186/1471-2261-8-40

GJESING AP, ANDERSEN G, ALBRECHTSEN A, GLÜMER C, BORCH-JOHNSEN K, JØRGENSEN T, HANSEN T, PEDERSEN O: Studies of associations between the Arg389Gly polymorphism of the $\beta 1$-adrenergic receptor gene (ADRB1) and hypertension and obesity in 7677 Danish white subjects. Diabet Med 24: 392-397, 2007. https://doi.org/10.1111/j.1464-5491.2006.02031.x 
GREEN SA, TURKI J, BEJARANO P, HALL IP, LIGGETT SB: Influence of beta 2-adrenergic receptor genotypes on signal transduction in human airway smooth muscle cells. Am J Respir Cell Mol Biol 13: 25-33, 1995. https://doi.org/10.1165/ajrcmb.13.1.7598936

GREEN SA, TURKI J, INNIS M, LIGGETT SB: Amino-terminal polymorphisms of the human beta 2-adrenergic receptor impart distinct agonist-promoted regulatory properties. Biochemistry 33: 9414-9419, 1994. https://doi.org/10.1021/bi00198a006

GRUDELL ABM, SWEETSER S, CAMILLERI M, ECKERT DJ, VAZQUEZ-ROQUE MI, CARLSON PJ, BURTON DD, BRADDOCK AE, CLARK MM, GRASZER KM, KALSY SA, ZINSMEISTER AR: A Controlled pharmacogenetic trial of sibutramine on weight loss and body composition in obese or overweight adults. Gastroenterology 135: 1142-1154, 2008. https://doi.org/10.1053/j.gastro.2008.07.009

GU D, GE D, SNIEDER H, HE J, CHEN S, HUANG J, LI B, CHEN R, QIANG B: Association of $\alpha 1$ A adrenergic receptor gene variants on chromosome 8p21 with human stage 2 hypertension. J. Hypertens. 24: 1049-1056, 2006. https://doi.org/10.1097/01.hjh.0000226194.21311.2f

HANCHARD NA: Genetic susceptibility and single-nucleotide polymorphisms. Semin Fetal Neonatal Med 10: 283-289, 2005. https://doi.org/10.1016/j.siny.2005.01.001

HERNÁNDEZ-PACHECO G, GONZÁLEZ-HERMOSILLO A, MURATA C, YESCAS P, ESPÍNOLA-ZAVALETA N, MARTÍNEZ M, SERRANO H: Arg347Cys polymorphism of ala-adrenergic receptor in vasovagal syncope. Case-control study in a Mexican population. Auton Neurosci Basic Clin 183: 66-71, 2014. https://doi.org/10.1016/j.autneu.2014.01.005

HUNTGEBURTH M, LA ROSÉE K, TEN FREYHAUS H, BÖHM M, SCHNABEL P, HELLMICH M, ROSENKRANZ S: The Arg389Gly $\beta$ 1-adrenoceptor gene polymorphism influences the acute effects of $\beta$-adrenoceptor blockade on contractility in the human heart. Clin Res Cardiol 100: 641-647, 2011. https://doi.org/10.1007/s00392-011-0288-1

IACOVIELLO M, FORLEO C, SORRENTINO S, ROMITO R, DE TOMMASI E, LUCARELLI K, GUIDA P, PITZALIS MV: Alpha- and beta-adrenergic receptor polymorphisms in hypertensive and normotensive offspring. J Cardiovasc Med 7: 316-321, 2006. https://doi.org/10.2459/01.JCM.0000223252.34611.87

JESUS ÍC de, ALLE LF, MUNHOZ EC, SILVA LR da, LOPES WA, TURECK LV, PURIM KSM, TITSKI ACK, LEITE N: Trp64Arg polymorphism of the ADRB3 gene associated with maximal fat oxidation and LDL-C levels in non-obese adolescents. J Pediatr 94: 425-431, 2018. https://doi.org/10.1016/i.jped.2017.07.010

JIANG S, MAO G, ZHANG S, HONG X, TANG G, LI Z, LIU X, ZHANG Y, WANG B, XU X, WANG X: Individual and joint association of $\alpha 1 \mathrm{~A}$-adrenergic receptor Arg347Cys polymorphism and plasma irbesartan concentration with blood pressure therapeutic response in Chinese hypertensive subjects. Clin Pharmacol Ther 78: 239-248, 2005. https://doi.org/10.1016/j.clpt.2005.06.003

JOHNSON AD, NEWTON-CHEH C, CHASMAN DI, EHRET GB, JOHNSON T, ROSE L, RICE K, VERWOERT GC, LAUNER LJ, GUDNASON V, LARSON MG, CHAKRAVARTI A, PSATY BM, CAULFIELD M, VAN DUIJN CM, RIDKER PM, MUNROE PB, LEVY D: Association of hypertension drug target genes with blood pressure and hypertension in 86588 individuals. Hypertension 57: 903-910, 2011. https://doi.org/10.1161/HYPERTENSIONAHA.110.158667

JOHNSON JA, ZINEH I, PUCKETT BJ, MCGORRAY SP, YARANDI HN, PAULY DF: B1-Adrenergic Receptor Polymorphisms and Antihypertensive Response To Metoprolol. Clin Pharmacol Ther 74: 44-52, 2003. https://doi.org/10.1016/S0009-9236(03)00068-7

JOSEPH SS, LYNHAM JA, GRACE AA, COLLEDGE WH, KAUMANN AJ: Markedly reduced effects of (-)isoprenaline but not of (-)-CGP12177 and unchanged affinity of beta-blockers at Gly389-beta1-adrenoceptors compared to Arg389-beta1-adrenoceptors. $\mathrm{Br} \quad \mathrm{J}$ Pharmacol 142: 51-56, 2004. https://doi.org/10.1038/sj.bjp.0705753

KATSAROU M-S, KARATHANASOPOULOU A, ANDRIANOPOULOU A, DESINIOTIS V, TZINIS E, DIMITRAKIS E, LAGIOU M, CHARMANDARI E, ASCHNER M, TSATSAKIS AM, CHROUSOS GP, DRAKOULIS N: Beta 1, Beta 2 and Beta 3 adrenergic receptor gene polymorphisms in a Southeastern European population. Front Genet 9: 2018. https://doi.org/10.3389/fgene.2018.00560 
KELLEY EF, SNYDER EM, JOHNSON BD: Influence of Beta-1 adrenergic receptor genotype on cardiovascular response to exercise in healthy subjects. Cardiol Res 9: 343-349, 2018. https://doi.org/10.14740/cr785

KELSEY RM, ALPERT BS, DAHMER MK, KRUSHKAL J, QUASNEY MW: Alpha-adrenergic receptor gene polymorphisms and cardiovascular reactivity to stress in Black adolescents and young adults. Psychophysiology 49: 401-412, 2012. https://doi.org/10.1111/j.1469-8986.2011.01319.x

KENAKIN T: New concepts in pharmacological efficacy at 7TM receptors: IUPHAR review 2. Br J Pharmacol 168: 554-575, 2013. https://doi.org/10.1111/j.1476-5381.2012.02223.x

KIM S, MISRA A: SNP genotyping: technologies and biomedical applications. Annu Rev Biomed Eng 9: 289-320, 2007. https://doi.org/10.1146/annurev.bioeng.9.060906.152037

KINDERMANN M, SEELAND U, RUHNKE P, BÖHM M, MAACK C: Functional effects of $\beta 1$-adrenoceptor polymorphisms on the hemodynamic response to dobutamine with and without b-blocker administration. Clin Res Cardiol 100: 129-137, 2011. https://doi.org/10.1007/s00392-010-0221-z

KOMARA M, VASUDEVAN R, ISMAIL P, BAKAR SA, PISHVA SR, HEIDARI F: Association of beta 2 adrenoceptor gene polymorphisms in Malaysian hypertensive subjects. Genet Mol Res 13: 2939-2948, 2014. https://doi.org/10.4238/2014.April.16.2

KUMAR S, MISHRA A, SRIVASTAVA A, MITTAL T, GARG N, MITTAL B: Significant role of ADRB3 rs4994 towards the development of coronary artery disease. Coron Artery Dis 25: 29-34, 2014. https://doi.org/10.1097/MCA.0000000000000056

KUNEŠ J, ZICHA J: The interaction of genetic and environmental factors in the etiology of hypertension. Physiol. Res. 58: 33-42, 2009. https://doi.org/10.33549/physiolres.931913

KURNIK D, MUSZKAT M, LI C, SOFOWORA GG, FRIEDMAN EA, SCHEININ M, WOOD AJJ, STEIN CM: Genetic variations in the $\alpha(2 \mathrm{~A})$-adrenoreceptor are associated with blood pressure response to the agonist $\begin{array}{llllll}\text { dexmedetomidine. } & \text { Circ } & \text { Cardiovasc }\end{array}$ https://doi.org/10.1161/CIRCGENETICS.110.957662

LA ROSÉE K, HUNTGEBURTH M, ROSENKRANZ S, BÖHM M, SCHNABEL P: The Arg389Gly beta1-adrenoceptor gene polymorphism determines contractile response to catecholamines. Pharmacogenetics 14: 711-716, 2004. https://doi.org/10.1097/00008571-200411000-00001

LEE HY, CHUNG WJ, JEON HK, SEO HS, CHOI DJ, JEON ES, KIM JJ, SHIN JH, KANG SM, LIM SC, BAEK SH: Impact of the $\beta-1$ adrenergic receptor polymorphism on tolerability and efficacy of bisoprolol therapy in korean heart failure patients: Association between $\beta$ adrenergic receptor polymorphism and bisoprolol therapy in heart failure (ABBA) study. Korean J Intern Med 31: 277-287, 2016. https://doi.org/10.3904/kjim.2015.043

LEI B, MORRIS DP, SMITH MP, SVETKEY LP, NEWMAN MF, ROTTER JI, BUCHANAN TA, BECKSTROMSTERNBERG SM, GREEN ED, SCHWINN DA: Novel human ala-adrenoceptor single nucleotide polymorphisms alter receptor pharmacology and biological function. Naunyn Schmiedebergs Arch Pharmacol 371: 229-239, 2005. https://doi.org/10.1007/s00210-005-1019-9

LEINEWEBER K, BRODDE OE: $\beta 2$-adrenoceptor polymorphisms: Relation between in vitro and in vivo phenotypes. Life Sci. 74: 2803-2814, 2004. https://doi.org/10.1016/j.lfs.2003.10.025

LEINEWEBER K, BRUCK H, TEMME T, HEUSCH G, PHILIPP T, BRODDE O: The Arg389Gly beta1-adrenoceptor polymorphism does not affect cardiac effects of exercise after parasympathetic inhibition by atropine. Pharmacogenet Genomics 16: 9-13, 2006. https://doi.org/10.1097/01.fpc.0000184956.16077.93

LEINEWEBER K, BÜSCHER R, BRUCK H, BRODDE O-E: Beta-adrenoceptor polymorphisms. Naunyn. Schmiedebergs. Arch. Pharmacol. 369: 1-22, 2004. https://doi.org/10.1007/s00210-003-0824-2

LEVIN MC, MARULLO S, MUNTANER O, ANDERSSON B, MAGNUSSON Y: The myocardium-protective Gly-49 variant of the $\beta 1$-adrenergic receptor exhibits constitutive activity and increased desensitization and down-regulation. J Biol Chem 277: 30429-30435, 2002. https://doi.org/10.1074/jbc.M200681200

LI Y, YUAN H, SUN L, ZHOU Q, YANG F, YANG Z, LIU D: $\beta 2$-Adrenergic Receptor Gene Polymorphisms Are Associated with Cardiovascular Events but not All-Cause Mortality in Coronary Artery Disease Patients: A Meta-Analysis of Prospective Studies. Genet Test Mol Biomarkers 23: 124-137, 2019. https://doi.org/10.1089/gtmb.2018.0153 
LI YY, LU XZ, WANG H, ZHOU YH, YANG XX, GENG HY, GONG G, KIM HJ: ADRB3 gene Trp64Arg polymorphism and essential hypertension: A meta-analysis including 9,555 subjects. Front Genet 9: 1-10, 2018. https://doi.org/10.3389/fgene.2018.00106

LIMA JJ, FENG H, DUCKWORTH L, WANG J, SYLVESTER JE, KISSOON N, GARG H: Association analyses of adrenergic receptor polymorphisms with obesity and metabolic alterations. Metabolism 56: 757-765, 2007. https://doi.org/10.1016/j.metabol.2007.01.007

LYMPEROPOULOS A, CORA N, MANING J, BRILL AR, SIZOVA A: Signaling and function of cardiac autonomic nervous system receptors: Insights from the GPCR signalling universe. FEBS J. 288: 2645-2659, 2021. https://doi.org/10.1111/febs.15771

MAHESH KUMAR KN, RAMU P, RAJAN S, SHEWADE DG, BALACHANDER J, ADITHAN C: Genetic polymorphisms of betal adrenergic receptor and their influence on the cardiovascular responses to metoprolol in a South Indian population. J Cardiovasc Pharmacol 52: 459-466, 2008. https://doi.org/10.1097/FJC.0b013e31818d3878

MASON DA, MOORE JD, GREEN SA, LIGGETT SB: A gain-of-function polymorphism in a G-protein coupling domain of the human beta1-adrenergic receptor. J Biol Chem 274: 12670-12674, 1999. https://doi.org/10.1074/jbc.274.18.12670

MASUO K, KATSUYA T, FU Y, RAKUGI H, OGIHARA T, TUCK ML: B2-Adrenoceptor Polymorphisms Relate To Insulin Resistance and Sympathetic Overactivity As Early Markers of Metabolic Disease in Nonobese, Normotensive Individuals. Am J Hypertens 18: 1009-1014, 2005 a. https://doi.org/10.1016/j.amjhyper.2005.01.006

MASUO K, KATSUYA T, FU Y, RAKUGI H, OGIHARA T, TUCK ML: B2- and B3-adrenergic receptor polymorphisms are related to the onset of weight gain and blood pressure elevation over 5 years. Circulation 111: 3429-3434, 2005b. https://doi.org/10.1161/CIRCULATIONAHA.104.519652

MATSUNAGA T, YASUDA K, ADACHI T, GU N, YAMAMURA T, MORITANI T, TSUJIMOTO G, TSUDA K: Alpha-adrenoceptor gene variants and autonomic nervous system function in a young healthy Japanese population. J. Hum. Genet. 52: 28-37, 2007a. https://doi.org/10.1007/s10038-006-0076-3

MATSUNAGA T, YASUDA K, ADACHI T, GU N, YAMAMURA T, MORITANI T, TSUJIMOTO G, TSUDA K: Association of $\beta$-adrenoceptor polymorphisms with cardiac autonomic modulation in Japanese males. Am Heart J 154: 759-766, 2007b. https://doi.org/10.1016/j.ahj.2007.03.053

MCCAFFERY JM, POGUE-GEILE MF, FERRELL RE, PETRO N, MANUCK SB: Variability within $\alpha$ - and $\beta$-adrenoreceptor genes as a predictor of cardiovascular function at rest and in response to mental challenge. J Hypertens 20: 1105-1114, 2002. https://doi.org/10.1097/00004872-200206000-00021

MICHEL LYM, FARAH C, BALLIGAND JL: The Beta3 Adrenergic Receptor in Healthy and Pathological Cardiovascular Tissues 9: 1-22, 2020. https://doi.org/10.3390/cells9122584

MIRRAKHIMOV AE, KERIMKULOVA AS, LUNEGOVA OS, MOLDOKEEVA CB, ZALESSKAYA Y V, ABILOVA SS, SOVHOZOVA NA, ALDASHEV AA, MIRRAKHIMOV EM: An association between TRP64ARG polymorphism of the B3 adrenoreceptor gene and some metabolic disturbances. Cardiovasc Diabetol 10: 1-7, 2011. https://doi.org/10.1186/1475-2840-10-89

MITRA SR, TAN PY, AMINI F: Association of ADRB2 rs1042713 with obesity and obesity-related phenotypes and its interaction with dietary fat in modulating glycaemic indices in malaysian adults. J Nutr Metab 2019: 8718795, 2019. https://doi.org/10.1155/2019/8718795

NEWTON-CHEH C, GUO CY, WANG TJ, O’DONNELL CJ, LEVY D, LARSON MG: Genome-wide association study of electrocardiographic and heart rate variability traits: The Framingham Heart Study. BMC Med Genet 8: 1-8, 2007. https://doi.org/10.1186/1471-2350-8-S1-S7

NUNES RAB, BARROSO LP, DA COSTA PEREIRA A, KRIEGER JE, MANSUR AJ: Gender-related associations of genetic polymorphisms of $\alpha$-adrenergic receptors, endothelial nitric oxide synthase and bradykinin B2 receptor with treadmill exercise test responses. Open Hear 1: 2014. https://doi.org/10.1136/openhrt-2014-000132

OHTA T: Selective Neutrality, In: Encyclopedia of Genetics. Academic Press, New York, pp 1800-1803, 2001. https://doi.org/10.1006/rwgn.2001.1168 
PIÉTRI-ROUXEL F, ST JOHN MANNING B, GROS J, STROSBERG AD: The biochemical effect of the naturally occurring Trp64 $\rightarrow$ Arg mutation on human $\beta 3$-adrenoceptor activity. Eur J Biochem 247: 1174-1179, 1997. https://doi.org/10.1111/j.1432-1033.1997.01174.X

POLANCZYK G, ZENI C, GENRO JP, GUIMARÃES AP, ROMAN T, HUTZ MH, ROHDE LA: Association of the adrenergic $\alpha 2 \mathrm{~A}$ receptor gene with methylphenidate improvement of inattentive symptoms in children and adolescents with attention-deficit/hyperactivity disorder. Arch Gen Psychiatry 64: 218-224, 2007. https://doi.org/10.1001/archpsyc.64.2.218

RANA BK, INSEL PA, PAYNE SH, ABEL K, BEUTLER E, ZIEGLER MG, SCHORK NJ, O'CONNOR DT: Population-based sample reveals gene-gender interactions in blood pressure in white Americans. Hypertension 49: 96-106, 2007. https://doi.org/10.1161/01.HYP.0000252029.35106.67

RANADE K, JORGENSON E, SHEU WH-H, PEI D, HSIUNG CA, CHIANG F, CHEN YI, PRATT R, OLSHEN RA, CURB D, COX DR, BOTSTEIN D, RISCH N: A polymorphism in the beta1 adrenergic receptor is associated with resting heart rate. Am J Hum Genet 70: 935-942, 2002. https://doi.org/10.1086/339621

RATHZ DA, BROWN KM, KRAMER LA, LIGGETT SB: Amino acid 49 polymorphisms of the human beta1adrenergic receptor affect agonist-promoted trafficking. J Cardiovasc Pharmacol 39: 155-160, 2002. https://doi.org/10.1097/00005344-200202000-00001

ROCHAIS F, VILARDAGA J-P, NIKOLAEV VO, BÜNEMANN M, LOHSE MJ, ENGELHARDT S: Real-time optical recording of beta1-adrenergic receptor activation reveals supersensitivity of the Arg389 variant to carvedilol. J Clin Invest 117: 229-235, 2007. https://doi.org/10.1172/JCI30012

ROKAMP KZ, STAALSOE JM, GARTMANN M, SLETGAARD A, NORDSBORG NB, SECHER NH, NIELSEN HB, OLSEN N V: G16R single nucleotide polymorphism but not haplotypes of the $\beta 2$-adrenergic receptor gene alters cardiac output in humans. Clin Sci 125: 191-198, 2013. https://doi.org/10.1042/CS20120555

ROSMOND R, BOUCHARD C, BJÖRNTORP P: A C-1291G polymorphism in the alpha2A-adrenergic receptor gene (ADRA2A) promoter is associated with cortisol escape from dexamethasone and elevated glucose levels. J Intern Med 251: 252-257, 2002. https://doi.org/10.1046/j.1365-2796.2002.00961.x

RYUK JA, ZHANG X, KO BS, DAILY JW, PARK S: Association of $\beta 3$-adrenergic receptor rs4994 polymorphisms with the risk of type 2 diabetes: A systematic review and meta-analysis. Diabetes Res. Clin Pract 129: 86-96, 2017. https://doi.org/10.1016/j.diabres.2017.03.034

SANDILANDS AJ, O'SHAUGHNESSY KM, YASMIN: B1-adrenoreceptor polymorphisms and blood pressure: 49S variant increases plasma renin but not blood pressure in hypertensive patients. Am J Hypertens 32: 447-451, 2019. https://doi.org/10.1093/ajh/hpz019

SCHMITZ M, DENARDIN D, SILVA TL, PIANCA T, ROMAN T, HUTZ MH, FARAONE S V., ROHDE LA: Association Between Alpha-2a-adrenergic Receptor Gene and ADHD Inattentive Type. Biol Psychiatry 60: 1028-1033, 2006. https://doi.org/10.1016/j.biopsych.2006.02.035

SHAHIN MH, ROUBY N El, CONRADO DJ, GONZALEZ D, GONG Y, LOBMEYER MT, BEITELSHEES AL, BOERWINKLE E, GUMS JG, CHAPMAN A, TURNER ST, PEPINE CJ, COOPER-DEHOFF RM, JOHNSON JA: $\beta 2$-Adrenergic Receptor Gene Affects the Heart Rate Response of $\beta$-Blockers: Evidence From 3 Clinical Studies. J Clin Pharmacol 59: 1462-1470, 2019. https://doi.org/10.1002/jcph.1443

SHIBATA K, HIRASAWA A, MORIYAMA N, KAWABE K, OGAWA S, TSUJIMOTO G: $\alpha$ (1a)-adrenoceptor polymorphism: Pharmacological characterization and association with benign prostatic hypertrophy. $\mathrm{Br} \mathrm{J}$ Pharmacol 118: 1403-1408, 1996. https://doi.org/10.1111/j.1476-5381.1996.tb15552.x

SI D, WANG J, XU Y, CHEN X, ZHANG M, ZHOU H: Association of common polymorphisms in b1-adrenergic receptor with antihypertensive response to carvedilol. J Cardiovasc Pharmacol 64: 306-309, 2014. https://doi.org/10.1097/FJC.0000000000000119

SKINNER BW, CURTIS KA, GOODHART AL: Hypnotics and Sedatives. Side Eff Drugs Annu 2018. https://doi.org/10.1016/bs.seda.2018.06.002

SNAPIR A, KOSKENVUO J, TOIKKA J, ORHO-MELANDER M, HINKKA S, SARASTE M, HARTIALA J, SCHEININ M: Effects of common polymorphisms in the $\alpha 1 \mathrm{~A}-, \alpha 2 \mathrm{~B}-, \beta 1-$ and $\beta 2$-adrenoreceptors on haemodynamic responses to adrenaline. Clin Sci 104: 509-520, 2003. https://doi.org/10.1042/CS20020299 
SNIEDER H, DONG Y, BARBEAU P, HARSHFIELD GA, DALAGEOGOU C, ZHU H, CARTER ND, TREIBER FA: $\beta 2$-adrenergic receptor gene and resting hemodynamics in European and African American youth. Am J Hypertens 15: 973-979, 2002. https://doi.org/10.1016/S0895-7061(02)02991-6

SNYDER EM, BECK KC, DIETZ NM, EISENACH JH, JOYNER MJ, TURNER ST, JOHNSON BD: Arg16Gly polymorphism of the $\beta 2$-adrenergic receptor is associated with differences in cardiovascular function at rest and during exercise in humans. J Physiol 571: 121-130, 2006. https://doi.org/10.1113/jphysiol.2005.098558

SOFOWORA GG, DISHY V, LANDAU R, XIE HG, PRASAD HC, BYRNE DW, SMILEY RM, KIM RB, WOOD AJJ, STEIN CM: $\alpha 1 \mathrm{~A}$-Adrenergic receptor polymorphism and vascular response. Clin Pharmacol Ther 75: 539-545, 2004.

SVOBODA P, TEISINGER J, NOVOTNÝ J, BOUŘOVÁ L, DRMOTA T, HEJNOVÁ L, MORAVCOVÁ Z, LISÝ V, RUDAJEV V, STÖHR J, VOKURKOVÁ A, ŠVANDOVÁ I, DURCHÁNKOVÁ D: Biochemistry of transmembrane signaling mediated by trimeric G proteins. Physiol Res 53 (Suppl 1): S141-S152, 2004.

TAVERNIER G, TOUMANIANTZ G, ERFANIAN M, HEYMANN MF, LAURENT K, LANGIN D, GAUTHIER C: $\beta 3$-Adrenergic stimulation produces a decrease of cardiac contractility ex vivo in mice overexpressing the human $\beta$ 3-adrenergic receptor. Cardiovasc Res 59: 288-296, 2003. https://doi.org/10.1016/S00086363(03)00359-6

TIKHONOFF V, HASENKAMP S, KUZNETSOVA T, THIJS L, JIN Y, RICHART T, ZHANG H, BRANDHERRMANN SM, BRAND E, CASIGLIA E, STAESSEN JA: Blood pressure and metabolic phenotypes in relation to the ADRB1 Arg389Gly and ADRA2B I/D polymorphisms in a White population. J Hum Hypertens 22: 864-867, 2008. https://doi.org/10.1038/jhh.2008.73

WARNE T, EDWARDS PC, LESLIE AGW, TATE CG: Crystal structures of a stabilized $\beta 1$-adrenoceptor bound to the biased agonists bucindolol and carvedilol 20: 841-849, 2012. https://doi.org/10.1016/j.str.2012.03.014

WILK JB, MYERS RH, PANKOW JS, HUNT SC, LEPPERT MF, FREEDMAN BI, PROVINCE MA, ELLISON RC: Adrenergic receptor polymorphisms associated with resting heart rate: The HyperGEN study. Ann Hum Genet 70: 566-573, 2006. https://doi.org/10.1111/j.1469-1809.2005.00258.x

WITTWER ED, LIU Z, WARNER ND, SCHROEDER DR, NADEAU AM, ALLEN AR, MURILLO CJ, ELVEBAK RL, AAKRE BM, EISENACH JH: Beta-1 and beta-2 adrenergic receptor polymorphism and association with cardiovascular response to orthostatic screening. Auton. Neurosci. Basic Clin 164: 89-95, 2011. https://doi.org/10.1016/j.autneu.2011.07.004

WU D, LI G, DENG M, SONG W, HUANG X, GUO X, WU Z, WU S, XU J: Associations between ADRB1 and CYP2D6 gene polymorphisms and the response to $\beta$-blocker therapy in hypertension. J Int Med Res 43: 424-434, 2015. https://doi.org/10.1177/0300060514563151

XIE C, HUA W, ZHAO Y, RUI J, FENG J, CHEN Y, LIU Y, LIU J, YANG X, XU X: The ADRB3 rs4994 polymorphism increases risk of childhood and adolescent overweight/obesity for East Asia's population: an evidence-based meta-analysis. Adipocyte 9: 77-86, 2020. https://doi.org/10.1080/21623945.2020.1722549

XIE HG, KIM RB, STEIN CM, GAINER J V, BROWN NJ, WOOD AJ: Alpha1 A-adrenergic receptor polymorphism: association with ethnicity but not essential hypertension. Pharmacogenetics 9: 651-656, 1999. https://doi.org/10.1097/00008571-199910000-00012

YAĞAR S, YAVAŞ S, KARAHALIL B: The role of the ADRA2A C1291G genetic polymorphism in response to dexmedetomidine on patients undergoing coronary artery surgery. Mol Biol Rep 38: 3383-3389, 2011. https://doi.org/10.1007/s11033-010-0446-y

YANG AC, TSAI S, HONG C, WANG C, CHEN T, LIOU Y, PENG C: Clustering Heart Rate Dynamics Is Associated with $\mathrm{b}$ - Adrenergic Receptor Polymorphisms: Analysis by Information-Based Similarity Index 6: 2011. https://doi.org/10.1371/journal.pone.0019232

YANG H, CAI D, ZHU Q, WU D, WANG Q, WANG Z: The mutation of Trp64Arg in $\beta 3$-adrenoreceptor-encoding gene is significantly associated with increased hypertension risk and elevated blood pressure: a meta-analysis. Oncotarget 8: 46480-46490, 2017. https://doi.org/10.18632/oncotarget.16666

YANG L-KK, TAO Y-XX: Physiology and pathophysiology of the $\beta 3$-adrenergic receptor, 1st ed. Prog. Mol. Biol. Transl. Sci. Elsevier Inc., Netherlands, 2019. https://doi.org/10.1016/bs.pmbts.2018.09.003 
ZHANG Y, HONG X, LIU H, HUO Y, XU X: Arg347Cys polymorphism of $\alpha 1$ A-adrenoceptor gene is associated with blood pressure response to nifedipine GITS in Chinese hypertensive patients. J Hum Genet 54: 360-364, 2009. https://doi.org/10.1038/jhg.2009.42 